\title{
CONCEPTUAL FRAMEWORK OF FAMILY WINERIES IN THE CZECH REPUBLIC: RESULTS OF A QUALITATIVE RESEARCH STUDY
}

\author{
Anastasia Murínová \\ ${ }^{1}$ Department of Management, Faculty of Business and Management, Brno University of Technology, Kolejní \\ 2906/4, 61200 Brno, Czech Republic
}

\begin{abstract}
MURÍNOVÁ ANASTASIA. 2018. Conceptual Framework of Family Wineries in the Czech Republic: Results of a Qualitative Research Study. Acta Universitatis Agriculturae et Silviculturae Mendelianae Brunensis, 66(4): 955-967.

The purpose of research is to understand the current situation and create a conceptual framework of a family business in the wine sector in the Czech Republic. Under this purpose, the following objectives were set: to find out the viability and usefulness of competitive tactics which influence the performance of micro and small family firms in the wine sector. These main competitive tactics have been established theoretically and require further practical confirmation. Another important partial objective was to verify the viability of family influence on the business performance in the framework of the study. Due to the lack of a sufficient theoretical basis in this sector, the author of the article puts the question, which indicators are used by selected firms for each tactic and how these firms percept and measure their performance. The research has a form of pilot study. The collecting of primary data was carried out using face-to-face structured interviews with ten representatives as a typical micro and small family business in the wine sector in the Czech Republic with considered restrictions. Then the content analysis was carried out using coding method and Atlas.ti software. The coded fragments and expressions were subsequently compared among themselves for the identification and interpretation of central categories. This investigation will serve to determine hypotheses in the larger parent study, which will be verified using quantitative methods. This research confirmed the authority of the competitive tactics, familiness and its influence on the business performance; and confirmed ability for practical application in the established reality. Results of the study are useful for both theorists and practitioners.
\end{abstract}

Keywords: family business, family wineries, competitive tactics, micro and small business

\section{INTRODUCTION}

Family firms have been guiding humanity for a very long time. They have historically laid the basis for business as such and are still an important part of national economies (Hesková and Vojtko, 2008). Usually, wine and gastronomy are ranked as exemplary bearers of the cultural identity of a region (López-Guzmán et al., 2014). The great tradition of different countries in grape cultivation and wine production (Kamsu-Foguem and Flammang, 2014) has resulted in becoming the world's largest wine producers and thereby tourism destinations
(Botero, et al., 2015; Lombardi et al., 2016). Czech wine industry is now a part of the industry which is rapidly developing and gaining momentum (Murinova, 2017). However, research on family business in the wine sector is practically non-existent (Soler et al., 2017), especially with regard to the Czech Republic. There is a potential advantage of the Czech Republic in the world market based on the natural and climatic conditions in this country ensure originality and exclusive taste of domestic wines (Šperková and Hejmalová, 2012). Czech wine industry is now part of the industry which is 
rapidly developing and gaining momentum. It is the particular part of the Czech wine industry given the significance of viticulture and winemaking for the agricultural economy of the Czech Republic, illustrated by 17,600 hectares of vineyards (Rozbroj, 2014). The number of enterprises with vine growing and the related production of wine is increasing. Special wine production such as the production of organic wines, straw wines or ice wines is also flourishing. Currently, it is typical of smaller family wineries rather than large agricultural enterprises. Even though most new micro, small and medium-sized Czech firms were established after 1989; wine production and trading existed for decades and is improving with each generation. However, there is a lack of any accurate statistics that would display the number of family firms in the Czech Republic including the wine sector (Svobodová et al., 2014). Although there are no accurate statistics, experts estimate are that up to $30 \%$ of businesses in the Czech Republic could be a family character. Today Czech law knows only the legal institute of the family plant institute enshrined in the new Civil Code, which is not sufficient for this purpose (Korab et al., 2008). It is not easy to say how large a percentage of GDP is made up of the family business in the Czech Republic. The Association of Small and Medium Enterprises of the country, however, estimates that today it is up to $30 \%$ (Brenova, 2015). Therefore, for scientific and national purposes, there is a need to study this topic.

Because the family firms in the Czech Republic are not thoroughly mapped and only now is time for handover to next generation it was decided to use the following definition of the family business in this research: "Family firm is a firm that is owned and controlled by one family or some members of that family; in addition, there is reason to believe that in the future the current generation will transfer its right of firm's ownership and management to the next generation". (Petlina, 2016) Respondents can be easily classified using this definition. Some authors agree with this definition, they add one important note, that it is a business, where spouses work together or their relatives (up to the third degree) work with at least one of the spouses; and this enterprise is owned by one of these persons (Janku and Marek, 2016). This note would help to reduce the number of business entities, which do not have any workers from the family.

Business performance is one of the main indicators that can show the real situation of a firm or the whole business sector (Mazzola et al., 2013). Besides that, it is necessary to explore the main factors that influence the business performance of family wine firms. Many factors could be responsible for explaining family business performance. Previous research indicates that competitive tactics and familiness influence business performance (Castillio-Apraiz and Matey, 2015; Klein et al., 2005). Competitive tactics play a key role in explaining various levels of organizational performance since they are the linkers between strategy formulation and implementation (Castillio-Apraiz and Matey, 2015). Integrating (as either moderating, mediating, or intervening) variables as familiness into main research might help increase the level of consciousness about the existence of familiness influence on business performance (Klein et al., 2005). The performance construct has the multidimensional nature, especially in family business case (Chrisman et al., 2012).

Therefore, topical areas for interviews were developed deductively, so the approach was formalized by some theoretical suppositions (Familiness, Competitive tactics and Business Performance). Thus, grounded circuits for interviews were theoretically generated, which are applied inductively.

The questions for the survey were formulated on the several main concepts that are mentioned before: business performance and factors influencing that performance (competitive tactics and familiness). For investigation of competitive tactics using the questions for respondents were formulated according to main competitive tactics: Quality-Oriented Competitive Tactics (Quality), Cost-Orientated Competitive Tactics (Cost), Innovation-Oriented Competitive Tactics (Innovation) and Marketing-Oriented Competitive Tactics (Marketing) (Castillio-Apraiz and Matey, 2015). An exploration of familiness and its influencing on the business was conducted basing on F-PEC scale and the following aspects: respondents' perception of family business and its advantages; family ties of involved family members into business and their activities in that business; management and ownership structure; decision making process and succession (Klein et al., 2005). This study shows the essence of business performance from a practical view. In this pilot study during the interviews respondents did not receive any specific aiming for specification and measurement tools of business performance. Thus, they were asked to self-identify how they understand this phenomenon and what tools they use to measure business performance. This was done in order to obtain pure information about respondents' understanding and identifying the business performance.

\section{MATERIALS AND METHODS}

A survey was conducted in the form of a pilot research, namely the face-to-face structured interviews, which belongs to the verbal form of questioning methods commonly employed in qualitative research. Open-ended questions were used in this study. This means that this type of research is completed by interviewer by using an audio recorder. The study supposed the use of open-ended questions due to the nature of the collected data favored as a means to illustrate findings and support the developed theory described above. a structured open-ended questionnaire and face-to-face interviews were used to obtain data 
in order to create a conceptual framework around a business performance of micro and small family business in the wine sector in the Czech Republic.

The pilot study is based on individual face-to-face interviews with individuals who have a direct relationship with the family business (owners, family members or business agents). During the interview, the questions were addressed to relative factors, which was created by the author based on aforementioned literature review and own view on needed determinative factors.

Received data was complete, in other words, there were no missing or incomplete answers. The sample includes representatives of the business, business owners and family members of the business owner. The research was focused on micro and small firms. a literary review allowed us to find out that most of the research on the wine sector is focused on large companies, we think the reason is that getting information from these firms is easier than from smaller ones. The study of competitive tactics and performance becomes difficult when the focus is placed on micro and small-sized firms, although their amount for about $99.8 \%$ of the companies in the EU-27 and $96 \%$ in the Czech Republic. In this study, size of the firms was measured by the number of employees, as it is recommended by Laevaert (2016).

In the analysis of respondents' answers, statements were decompounded and compared with each other; the author was inspired by the Constant Comparative Method known from the approach of Grounded Theory. 'Grounded Theory' (originated by Glaser and Strauss in 1967) is a well-known and frequently discussed form of inductive qualitative research. Obtained data were initially segmented; thus, individual responses to the questions in the interview were divided into individual statements embodying a selected topic. The topic was then coded. Open coding was applied, contained significance in the interviews was capture no matter to what theory assumes (Berger, 2009). Statements, date coding, and snippets then were compared among themselves; central categories were identified and interpretation subsequently was related to them, this interpretation is supplemented by-related categories. Atlas.ti was used for data analysis as it is one of the most popular available software for qualitative analysis.

The survey was conducted in November 2016. The sample of family businesses was limited to wine trading businesses that presented at the annual Czech national wine festival on Saint Martin's Day. Due to this, later primary research focus will be developed in a way that limits trading firms to use the data. The pilot study was carried out by conducting ten face-to-face interviews. All interviewed firms have a residence in the Southern Region of the Czech Republic. The research focuses on micro and small-sized family firms, which were identified by application of mentioned above definition of family business. The next condition for determination of family firm is the employment of at least one family member in a family business (Janku and Marek, 2016). Moreover, the two industries are closely related, many vine-growers also make wines; however, some winemakers do not farm vineyards of their own. This paper deals with the grape growing activities of those growers who farm vineyards and make wines simultaneously.

There are also limitations, such as the date of the wine festival (one day), when there was the opportunity to interview. a next limitation of the pilot study is the small number of respondents who were interviewed. Further primary quantitative research is supposed to conduct an interview with a large number of family wine firms. This small number of respondents is based on the following assumptions. According to Connelly (2008), extant literature suggests that a pilot study sample should be $10 \%$ of the sample projected for the larger parent study. Nevertheless, Hertzog (2008) previses that this is not a simple or straightforward issue to resolve because these types of studies are influenced by many factors. However, Isaac and Michael (1995) suggested 10-30 participants; Hill (1998) suggested 10 to 30 participants for pilots in survey research; Julious (2005) in the medical field and van Belle (2002) suggested 12; Treece and Treece (1982) suggested $10 \%$ of the project sample size. Thereby, 10 would be considered as an optimum in this case, because the sample size of the larger parent project is expected to be 100 .

\section{RESULTS AND DISCUSSION}

Based on the aforementioned conditions, qualitative exploratory research was conducted, obtained data were analyzed by means of Atlas. ti software. The results allow us to understand the current situation in the research field, create a conceptual framework for further research in combination with a theoretical support. The results were divided into three parts according to the main research areas: family influence on the family business in the wine sector, competitive tactics, and performance of the family business.

\section{Family influence}

\section{Family business perception}

Firstly, it is necessary to understand how respondents comprehend the family business phenomenon. a few regularities can be observed in family business perception, based on the statements of respondents. The majority of respondents mentioned that it is connected with several generations taking part in the business life: "Several generations work in the family firm." (Respondent A) Some respondents noted that the intention to transfer business to the next generation is fundamental to the family business despite the risk: "This is a business that will be transferred to the next generation. This is a very 
risky type of business because no one knows if the children will have an interest in continuing the business." (Respondent E) This feature that reported by respondents are also reflected in the definition of family business (cited above), subject to further research: „A family business is one owned and possibly controlled by a family, families, or by selected family member(s), whereas its delivery to the next generation is supposed". It should be noted that the mentioned definition of family business contains important lineaments as the ownership and control of the business by the family. Those lineaments are mentioned in the respondent' answers: "Family has full control over the business" (Respondent A), "Family business in the wine industry, I understand as a firm where the family manages the business and wine cellar after a previous generation." (Respondent F) Respondents also noted the presence of family traditions associated with the production of wine, as a characteristic feature of this definition (Fig. 1). Some papers emphasized that family ownership causes stagnation and reluctance to risk-taking, our study refutes these statements and assumes that full family ownership contributes for striving for accomplishing the well-being of future generations, the knowledge about the company and the field of business it operates in (Wiecek-Janka et al., 2016). This statement may form the basis of the hypothesis about the impact of family ownership on the performance in the future studies of scholars.

This finding corresponds to the theoretical background where that intention is the second of three key principals determining family business according to Vallone (2013). The results of the previous research show that such criteria supposing delivery of the business to the next generation are crucial for micro and small family firms (Hernández-Linares et al., 2018; Petlina, 2016; Korab et al, 2008).

Many respondents fully confirm theoretical statements about the impact the family definitely has on the business, simultaneously business has direct impact on the family: "The main advantage of family business is family traditions that keep the family together, make it stronger, teaching family to solve problems together and find solutions" (Respondent C) It is interesting to note that one of the main benefits of family involvement in the business is free labor: "Family (especially the narrower family, i.e. children and husbands/wives) provides additional relatively cheap labor." (Respondent G) This can be explained by the fact that the involvement of additional external manpower is either a backbreaking or an expensive means for micro and small businesses.

Every respondent claimed they inherited the business from their parents and in most cases, usually the third-generation members, also there is a craft in the second and fifth generation. Despite this fact, the newest micro, small and medium-sized Czech enterprises were established after 1989 (Korab at al., 2008). This shows that wine production and trading has existed for decades and is improving with each generation.

\section{Family ties}

For a better view of the current situation and for further study, respondents were questioned regarding their firm's management and the family member business involvement (the structure of family ties of involved members and their role in business). In most cases, the owner and manager is the same person, this represents the inseparable connection of control and ownership typical

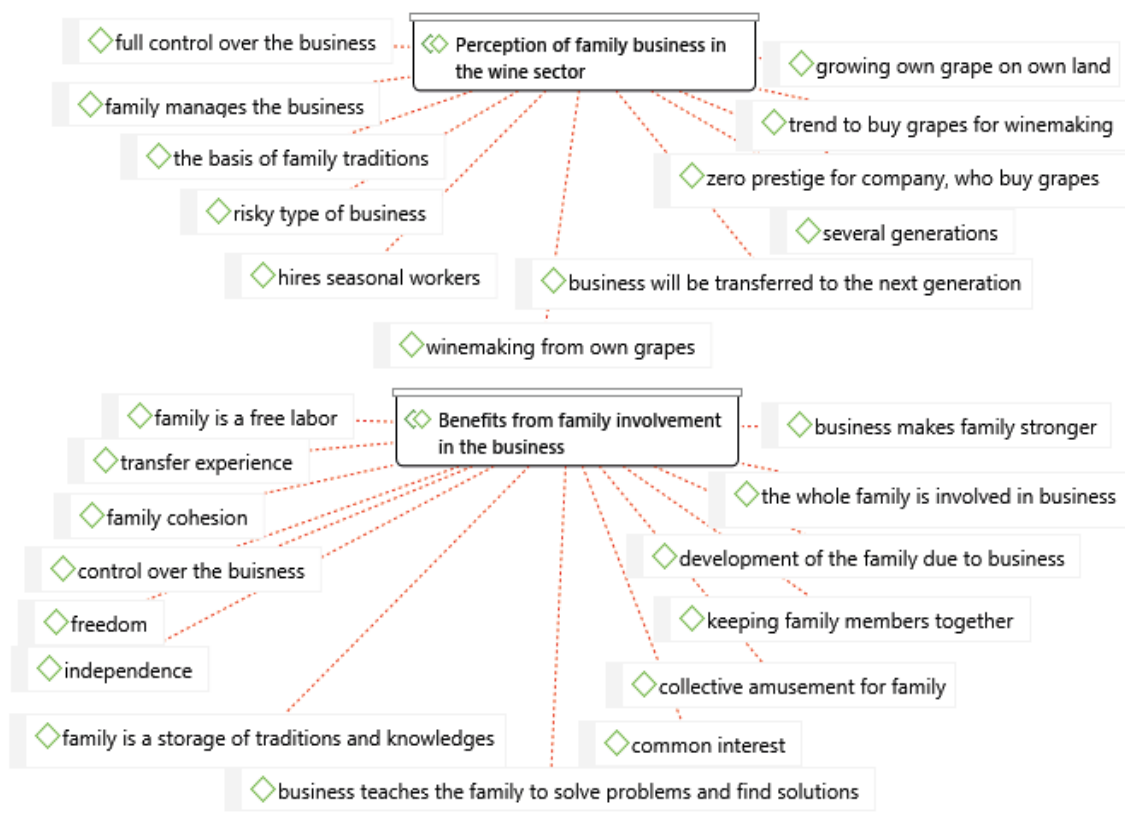

1: The major components of family business perception and benefits of family 
in micro and small business. Although in some cases, the separation of control and ownership occurs: "The official owner is my wife. We have three managers: manager for grape growing, production manager and marketing manager. These managers are our sons." (Respondent C) Respondents attributed this to the fact that in this way the older generation tries to make a gradual succession of the business to the younger generation, i.e., first, they pass on control over the business, and later ownership.

The most common types of family ties of this sample are following: "father-mother-son" and "father-son" (Fig. 2). These results are similar to last studies (Petlina, 2016). The following research will be able to identify the causes of this trend.

Regarding family member's business involvement, in particular, we can observe the basic activities which are associated with vineyard care, grape collection, and work in the wine cellar, realization and wine promotion.

\section{Decision making}

As described above, the F-PEC scale served for formulating the interview questions, it was necessary to investigate the decision-making process within the presented firms. The main result is confirmation of theoretical allegations, decision making about the business is a family process, regardless of the non-involvement of all family members participating in the family business: "We discuss all posers together." (Respondent I) This reveals the family has a direct impact on decision-making about the business: "Opinions of family members are valid." (Respondent B) Moreover, in some cases, there was a tendency to hold regular family meetings and discussions about the business and even mentioned the commitment of all family members to be present at such events: "Decision making about the business is a family process, where involved members have a meeting and discuss actual issues." (Respondent A) Although most studies have been based on the supposition that high levels of commitment are good, others have revealed the possible perils of high levels of commitment (Yu, Lindsay, 2016). Besides that, the deep face-to-face interviews confirm that commitment can have two faces: the first one, which aids to overcome obstacles and achieve evidently impossible goals; the second one is prodigal in which commitment evolves into entrapment such that resources are thrown after bad in attempts to execute impossible goals.

In addition, one of the most important indicators used in the F-PEC scale is the merge or the presence of common ideas and concepts of the family business and the ways of its development (Klein et al., 2005). All respondents narrated per presence of this association: "We create a common business vision together. Our family does not tend to follow someone's idea blindly about the business." (Respondent C) "Yes, of course, the family has common goals and views in management ideas". Family meetings were mentioned as a foundation for a successful discussion and making important decisions: "We organize periodically family meetings where we discuss main issues and business direction." (Respondent H) (Fig. 2).

\section{Succession}

One of the main conditions to be able to define family business is supposing business handover to the next generation (Koráb et al., 2008). For example, it is the second of three key principals of defining family business by Vallone (2013). Previous research results show that out of different definitions this criterion is used very little, that does not lead to study but it is significant for studying micro and small-family-owned firms in the Czech Republic that represents a great part of all business operations in the country (Petlina, 2016). In the actual research, the intention to pass the business on was determined

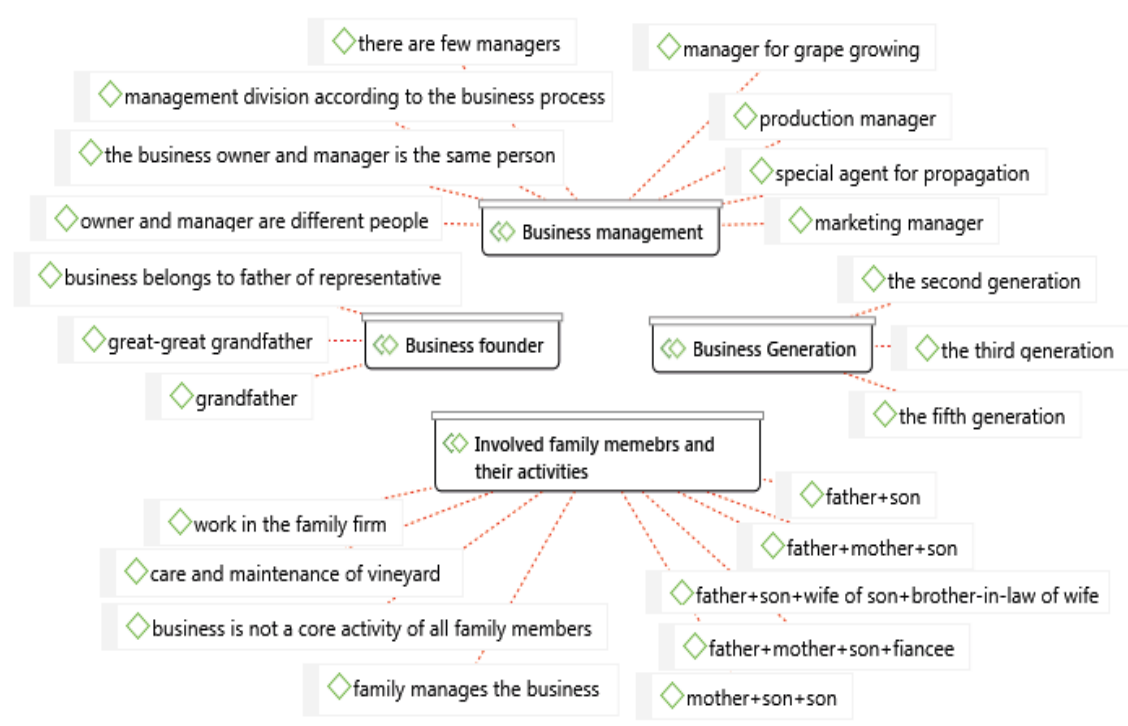

2: The major family ties of family member involvement and their business activities, family business founders, business management of representative sampling 
in each case. Without exception, all respondents say they expect further business succession to the next generation: "Yes, the business was originally set up so could continue the business in the future." (Respondent E) It is worth mentioning one important feature of the proposed succession. Many respondents focused on the existence of one condition in business succession: there is a need for desire and skills within the next generation representatives: "If my children are capable, I will transfer the business to them." (Respondent A)

\section{Competitive tactics and development direction}

With regards to the research objective, it was necessary to discover what kind of competitive tactics and development trends are essential for the representatives of micro and small wine companies in the Czech Republic. In this regard, several main trends were observed.

\section{Quality-oriented Competitive Tactics}

One of the main responding trends relates to the Quality-oriented competitive tactic. Seven respondents referred to focusing on their wine quality. For example, Respondent H said: "Our goal is to reach the end customer and offer him the best quality of a wine." "We have absolute control over the quality of the grapes so that we provide customers with the best we have and what we drink." (Respondent F) This competitive tactic also includes extended customer service that was mentioned in several other responses: "We are doing a show for the customers, we try to present our wine business in the best way. More so, quality wine is behind the show!" (Respondent E) Respondent G expressed: "We prefer to meet our clients face to face and offer them additional service: information about the grape cultivation and wine production, wine taste information and combinations with meals." Therefore, this tactic theoretically involves investment in research that was confirmed by respondents: "In order to keep pace with the time we devote time and available funds for various studies in the field of grape cultivation and experimenting in a production of new types of wine and Cuvée." (Respondent $\mathrm{H}$ )

\section{Cost-oriented Competitive Tactics}

The second main set of competitive tactics are Cost-oriented, the use of which has been noticed in three respondents. It mainly mentioned efforts to reduce production costs and final product prices: "We understand that our prices cannot be compared with the prices of huge wholesale companies but, despite this, we are trying to stay competitive on this market. We

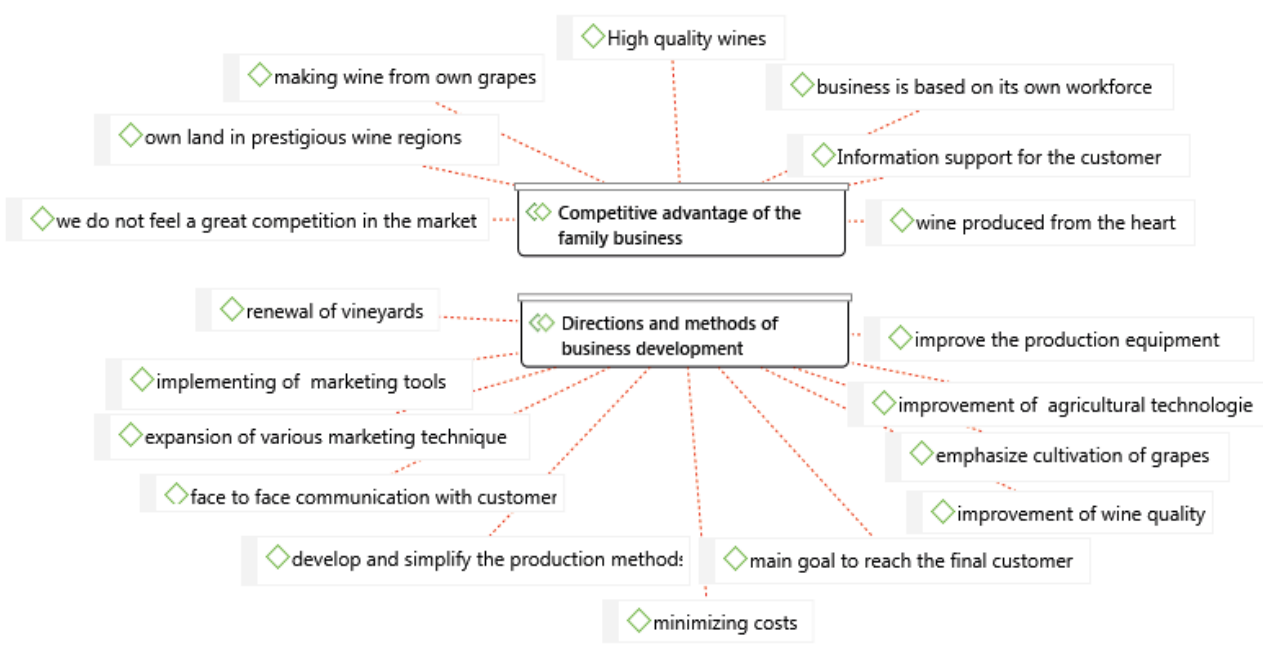

3: The major features of competitive advantages and development directions of the selected family firms

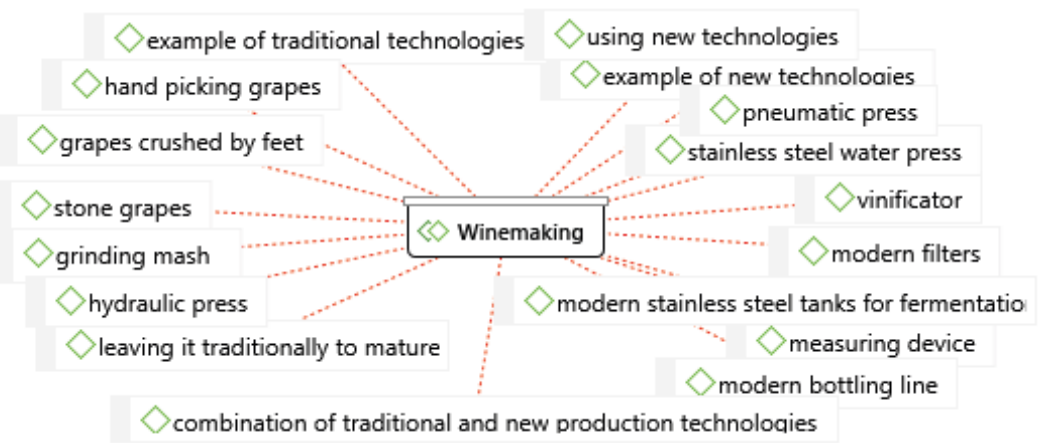

4: The main traditional and modern production methods and tools used by selected firms 
monitor the market prices and try to reduce production costs to diminish the final price of the wine." (Respondent I) For a detailed review of the major features of competitive advantages and development directions of the selected family firms, Fig. 3 represents a structured map.

\section{Innovation-Oriented Competitive Tactics}

The following trend in the development of micro and small wine businesses represents Innovation competitive tactics. The respondents' answers confirm theoretical claims related to this area. Respondents mentioned renewal of vineyards with use of modern technologies as one of the development directions: "Our vineyards are already relatively old. In the coming years, we will focus on the renewal of our vineyards. Also, we plan to use modern technologies, e.g. for irrigation improvement." (Respondent F) Improvement of agricultural technology including harvesting is also one of the expanding trends: "We emphasize grape cultivation and agricultural technology improvement, as well as focusing on facilitating harvesting." (Respondent D) One of the popular trends among respondents is developing and simplifying production.

Respondent answers indicate that within this ancient craft coexist traditions and innovation. In regards to wine production methods, there are combinations of ancient knowledge, family customs, time-tested traditional production methods, modern technologies, innovative tools, and machines. In this sense, wine production is unique and worth studying (Fig. 6). Respondent a listed the following items associated with classical winemaking: "For example, classical methods are hand picking grapes, grinding, seed removal, fermenting at low temperatures without adding additional yeast." Partial traditionalism makes this type of activity sophisticated: "Our firm likes to experiment with new technologies. But wine production fundamentals remain unchanged." (Respondent B) Nevertheless, innovation enables this field to not remain in the past and be a full-fledged modern activity. In Fig. 6 the main modern production methods and tools are displayed. Respondent a noted the next example of using innovation results: "With regards to modern technologies, we use a vinificator for red wine, we ferment mash in modern stainless steel tanks for 2-3 days." "The winery uses new technology for wine "Lavender Dude" production" as claims respondent G. Undoubtedly, such innovation requires a financial investment: "Our production is already completely based on new technologies. For example, controlled fermentation, pneumatic press, vinificator, usage of modern filters, modern bottling line, without these the production process cannot be executed. For further business development, we need a minimum of 150-200 thousand Czech crowns annually" (Respondent D); "Our recent investments in this respect were a stainless-steel water press, which replaced the old hydraulic press. Further investments will aim to replace the measuring devices (e.g. Acidity), to able to dose more accurately, e.g. pyrosulfite." (Respondent F) The combination of traditional and modern technologies with cultivation, harvesting, and wine production method makes the industry grow and thrive: "We use a combination of traditional and innovative methods" (Respondent E); "We follow old classical methods of wine production, but we use also new technologies" (Respondent A). Most respondents indicated the main feature of the micro and

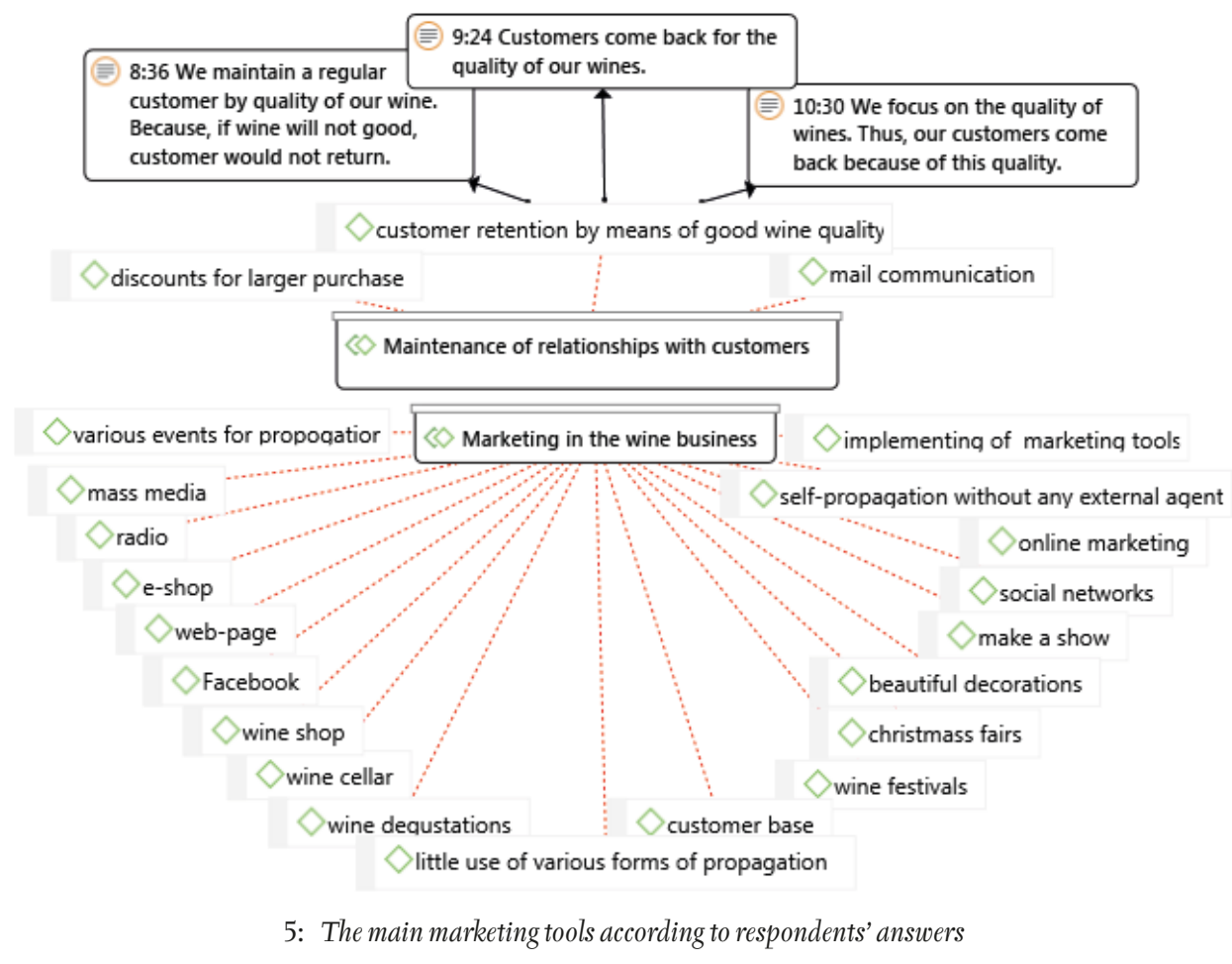


small family businesses in the wine industry is making of wine by heart: "In comparison to big companies, we make wine by heart" (Respondent G); "We are a family winery, we make our wine on our own estate by heart, and customers appreciate that." (Respondent C)

\section{Marketing-Oriented Competitive Tactics}

Marketing as the further competitive tactic is mentioned in several interviews. Generally, it is important to share new innovative marketing knowledge and effective marketing policies to build a sustainable competitive advantage in wine markets (Murinova, 2017). Marketing tactic can help wineries will help convey to the consumer those important distinctive features that family firms have, improving financial performance, minimizing costs and business risks and maximizing market opportunities (Christofi et al., 2015). Marketing is reflected in responses as focusing on promoting, advertising, emphasizing of a firm and its products in the market: "We expand various marketing techniques to promote our wines" (Respondent I). Marketing orientation was detected in efforts to create a database of regular customers and retain them: "For the time being, we are addressing potential customers more directly and are trying to build a customer base" (Respondent F). All selected firms presented themselves as modern firms trying to follow the current communication methods, techniques to attract and retain customers (Fig. 5).

Many respondents indicate that they're using online marketing tools (web-pages, e-shops, social media promotion) for their marketing purposes: "We actively use online marketing tools, particularly social media, such as Facebook" (Respondent G); "For product and brand promotion we actively use social networks, for example. Facebook. It works well. Also, we have our own web page and e-shop." (Respondent D) The radio is also a promotion means: "Sometimes before a big event we order advertising in mass media such as radio" (Respondent D); "On occasion, we use a radio." (Respondent C) Event marketing is very popular among the respondents: "New customers can get to know about us on wine tastings."
(Respondent A) Some firms employ a special agent for this. Some firms cannot afford a special agent for such purposes because it requires additional costs beyond the budget of starting wineries: "We self-promote without an external agency." (Respondent A) Respondents mentioned wine quality as a mean for customer retention (Fig. 5).

\section{Business performance}

Research on family firms' performance is growing. Although previous international research has questioned the ability of family firms to perform well (Miller et al., 2007), our study focuses on the analysis of the performance features of micro and small family wine firms. Following Mazzi (2011) and De Massis et al. (2013) we agree that family firms are heterogeneous entities and thus some factors may influence or moderate this relationship. In regards to the research task, it is necessary to identify the performance perception of micro and small wine businesses from a practical perspective, taking into account that it is a family business. There is no or little coherence on how to measure the performance of a small firm, which is best approached by a case (Richard et al., 2009; CheZuriana and Mohamed, 2011). For this purpose, many authors offer to use financial and non-financial indicators together (Hornungová and Milichovský, 2013). But multidimensional aspects, hybrid measures, and improved performance indicators were proposed as it is strong enough to grasp different approaches (Simpson et al., 2012). Several regularities can be observed in business performance perception based on the following statements. The respondents mentioned that it relates to financial and non-financial measures. From a finance perspective, respondents noticed a profit: "I understand business performance with the help of turnover and profit analysis." (Respondent E) The respondent is using two measurements which include turnover. "Therefore, our firm does not report a profit. But we are tracking our turnover, which is constantly increasing." It is worth noting that this is a typical problem for private businesses with

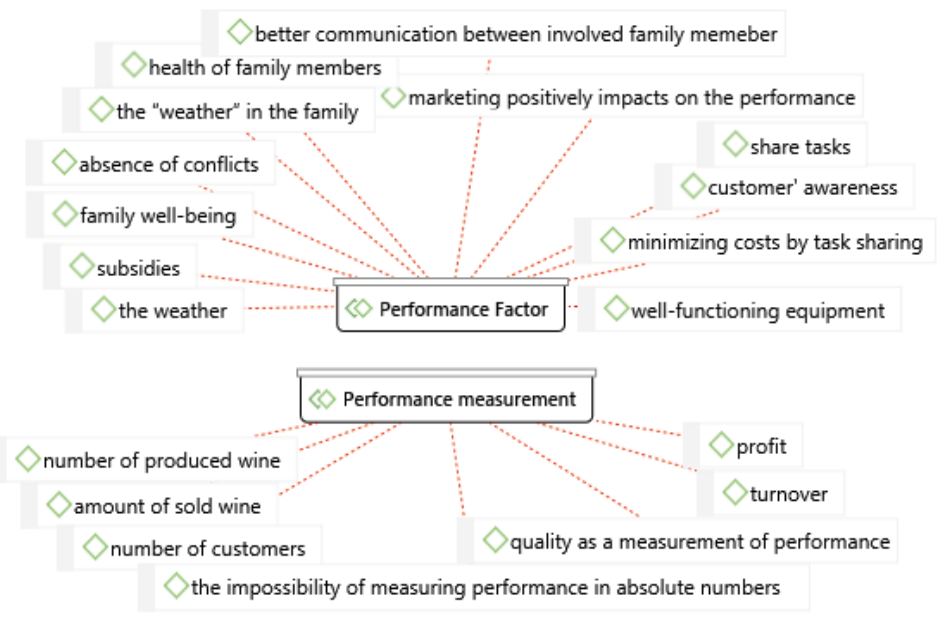

6: Performance measurements and factors influencing business performance according to respondents' answers 
all the profit based on financial indicators, where is corporate income tax or tax on business owner's income. Besides these, the variety in methods of accounting routines in private firms contributes to the difficulties of processing financial information provided by a private firm (Ling, Kellermanns, 2010), that prompts to minimize reported taxable income (Mazzi, 2011).

Other non-financial measures are a number of sold wine was applied to explain business performance: "Our performance is increasing along with the increasing amount of produced and sold wine bottles." (Respondent A) The addition of a number of sold wine, that respondent mentioned as a number of produced wine. "I understand business performance by means of a number of produced wine. Our business production grows by 10 percent per year on average." (Respondent D) It is specifically true for the wine industry. Because wines that were made in a certain reporting period are not necessarily sold in the same period, because some wines need to be stored to mature before being sold. It may take several months to several years for the wine to age. In addition, there are archival wines, which are sold decades after their production. Respondent F implies a ratio of produced and sold wine: "We evaluate business performance by the ratio of produced and sold wine." This respondent made the important observation that their firm keeping track of such measurement in absolute numbers is arguable because different measurement periods have different conditions.

The applied measurement for business performance that respondents mentioned is customer measures: "We evaluate our business performance through the number of customers, if this number is increasing that means our performance is also increasing." (Respondent I) Customer satisfaction was marked as an important measurement for business performance: "For us it is especially important to see that our customers are satisfied with the quality of wine, packaging, service, additional options etc." (Respondent G) It is worth noting either that wine quality itself is considered as a measure of business performance: "We are very happy when we know that the wine quality increases that shows us that we are moving in the right direction and our business performance increases." (Respondent D) Thus, respondents use various tools to describe to explain and evaluation of business performance. Multidimensional aspects and hybrid measures are used, which confirm the theory (Simson et al., 2012).

Generally, family business literature identifies many factors that can be responsible for firm's performance. Moreover, Martin-Reyna and Duran-Encalada (2012) argue that the better or worse performance of family firms depends on the context of each country. In this context, we will highlight the main factors that, according to respondents, can affect performance for their most durable use in quantitative research.

There are several tendencies in the factors influencing the business performance of micro and small family wine businesses (see Fig. 6). As one of most influential external factors respondents named the weather, which consequently affects the harvest in quantitative and qualitative ways. The next external factor are subsidies: "Subsidies have a positive effect on the business performance. For instance, this year we used subsidies to restructure vineyards." (Respondent C) Respondents later put more emphasis on internal factors that affect business performance. It is worth noting that a significant portion of the factors which are connected to the fact that it is a family business, and that factors are based on family influence, on business, and vice versa: "The most important factor for winemakers is the weather in the general meaning and the "weather" in the family" (Respondent A); "Family well-being, absence of conflicts, health of family members" (Respondent E); "I think that the main factor is a healthy relationship in the family." (Respondent G) In addition, Respondent J added that they minimize costs by task sharing as a part of the factors influencing the business performance. Besides, respondents mentioned customer awareness as a factor: "Customer awareness about our business and our products directly affects our business." (Respondent I) Customer awareness is influenced by emotions (cognition, affection, and conation) and customer purchasing intention, thus, affects the number of products sold. In regards to, other factors influencing business performance respondents noticed well-functioning equipment: "Apart from the fact that production capacity should always be in order, you must also have modern and high-quality equipment" (Respondent G). Respondents recognize the usage of new technologies as an important contributing factor to their business: "The implementation of new technologies saves time in the future and allows you to reach a new level of quality, production, and positive impact in reducing production costs" (Respondent B). That confirms the results of Mason et al. (2016), who assume that internal innovation enables wine firms to stay competitive in the marketplace. It also allows wine firms to respond quickly to competitors, thus producing newer and better products that tailor to the needs of the consumers and society. Moreover, we agree with Fiore et al. (2017), that innovations might lead to the consideration that small and medium-sized enterprises (SMEs) involved in wine supply chain, should shift towards greener business-oriented models in order to sustain their market competitiveness. The last of the principal factors is marketing that in our case positively impacts business performance, based on respondents answers: "The correct use of marketing tools enables attaining good business performance" (Respondent F); "Using of marketing tools directly effects our business." (Respondent B)

The obtained results will help scholars to understand the actual situation of these firms, to establish hypothesis and develop scales for competitive tactics and family business performance in the wine sector. 


\section{CONCLUSION}

One of the main output of the research is the determination of how family firms perceive micro and small family business in the wine sector, what features and benefits it has. According to the results, the study phenomenon is business where several family generations are involved and family has full ownership and control over the business; plus, a family owner has the intention to transfer the business to the next generation. That is important and allow us to use obtained definition in the next research as the base. Besides that, we discover that majority of family members have other jobs, and working for the family in the wine business is secondary. The revealed benefits of family involvement in the business is a free labor, joint pastime, entertainment option, and keeping the family together. The next important finding is that decision making about the business is a family process, regardless of the non-involvement of all family members in the family business. This supports choice and necessity to measure the influence of familiness on business performance. Moreover, in some cases, a tendency to have regular family meetings and discussions about business issues were detected, which gives grounds for the prolongation and development of strategic ideas and competitive tactics (Aronoff, Ward, 2011). As an important concept of the F-PEC scale, the relation of common ideas of family and business managers about the business was investigated.

The results of research draw a general picture of the structure of micro and small family wine firms, family ties, ownership, and management. Most represented businesses have been developed by the third generation that allows us to establish the futures research' hypothesis basing on the differences between firms' generations. The most common type of family ties in this sample is "father-son" that confirms results of previous studies in this field (Murinova, 2017). The next finding is a tendency of male predominance in the involvement in business within this sector. In the following research, the focus on the causes of this trend and female involvement may be appropriate. Furthermore, business owner and manager is the same person which indicates an inseparable link between ownership and control which is typical for micro and small business. But in several cases, there is a division of ownership and management. From our point of view that can be ascribed as a gradual succession of the business from parents (owners) to a younger generation thereby firstly, they transfer the business control (management) and then the business ownership. This provides a great opportunity for further dipper study of this issue.

Next part of conclusion sheds light on possible factors influencing the business performance that are associated with the use of competitive tactics. The main output of the study is a clarification of the presence and meaning of competitive tactics as well as development orientation of the respondents' business. Several trends were formulated confirming certain proposed theoretical competitive tactics (Quality, Cost, Marketing, and Innovation. The first relates to Quality as a competitive tactic resulting in a focus on extended customer service and the wine quality of the respondents' own business. This also includes investment in research associated with business development, e.g. modification of the grape variety used in wine production or Cuvée invention. This competitive tactic is important for pioneering firms concentrating on quality and strive to be first-to-market. The next confirmed competitive tactic is Cost, which is manifested in the reduction of production costs and final product prices. Market followers conform with this tactic, in sum, the firm that adapts to the ideas or inventions of pioneers. Innovation is the next confirmed competitive tactics, which in micro and small family wine firms includes the following aspects: vineyards renewal with the use of modern technologies, irrigation modifications, improvement of agricultural technologies (including harvesting facilitating), developing and simplifying production with help of new technologies and techniques. One of the important results that there is a coexistence of both traditions and innovations that is the main instigative feature of this field. Keeping traditions alive is important for teaching the next generation. Innovation enables this field to become a full-fledged modern activity. The study deals with the perception of wine marketing and its tools as a competitive tactic of micro and small family wine firms. Micro and small family wine forms' marketing focuses on promoting, advertising, emphasizing of a firm and its products on the market, where the main purpose is to create a loyal customer base and retain it. The perception of marketing's purpose to drive sales is secondary. The focus on their promotion emphasized quality as a mean for customer retention. Every interviewed firm identified itself with using modern and convenient ways of communicating with customers. Thereby, there is space for conducting a thorough study to carry out, which marketing tools are more influential in terms of performance of family wine firm to increase their competitiveness.

One of the main research results is the determination of family winefirms' performance measurements. Profit and turnover are financial measures. In some cases, profit was not considered as an appropriate measure due to the firm's small size and inability to be profitable. Therefore, turnover is a meaningful measuring for this business. In addition, sales (amount of sold wine), a number of produced wine, and the ratio of produced and sold can be used to measure business performance particularity for the wine industry. Furthermore, for non-financial measures of the performance, the study reviled 
"customer measures", such as a number of customers and customer satisfaction. It is worth noting that either wine quality itself is viewed as a measure of business performance. Respondents accent on internal factors that affect the business performance. Most of these factors are connected to the fact that this is a family business, and these factors are based on the family's influence on business and vice versa. Following trends were identified: "weather" in the family". These findings contribute to theoreticians and practitioners who intend to measure the performance of micro and small family wine firms to develop or update scale for performance measures, which will include financial and non-financial measures, business and family measures corresponding to business and family goals. Finally, this study suggests a theoretical grounding for this economically important yet underresearched domain of family firms. The paper makes multiple contributions to the literature. First, it contributes to the family business literature by introducing an individual comprehension and benefits of this kind of business from the point of view of the family businessmen themselves. Second, the structure of family ties, generational involvement, decision-making process, and succession were described in details. Moreover, this study provides the first empirical results of the implementation of different competitive tactics such as Quality-Oriented Competitive Tactics, Cost-Orientated Competitive Tactics, Innovation-Oriented Competitive Tactics and Marketing-Oriented Competitive Tactics. The study confirmed the application of these tactics by family wine firms, which allows us to study these relationships in further quantitative research. Besides, the study can help scholars in determining indicators for each factor (tactic) affecting the performance of a family wine company. Family business research to date has been hampered by the absence of well-developed theory in the wine sector, as well as by a paucity of data about this substantial segment of the Czech economy. Our extension of competitive tactics' theory to this domain, coupled with the primary data, helps to illuminate the current situation and create a conceptual framework of a family business in the wine sector in the Czech Republic while paving the way to future prospects for research. Besides, detected measures for performance of wine firm can be used in the further studies. In addition, future research should seek to gather data to provide additional insight into the use of the competitive tactics on the family business performance in the wine sector. Moreover, the relationship between tactics and performance should be studied using econometric methods such as structural equational modeling.

Acknowledgement

This paper was supported by project "Výzvy řízení a fungování podniku v kontextu současného podnikatelského prostředí" [FP-S-18-5395].

\section{REFERENCES}

ARONOFF, C. E. and WARD, J. L. 2011. Family meetings: How to build a stronger family and a stronger business, New York: Palgrave Macmillan.

BERGER, R. 2009. Review: Ann Lewins \& Christina Silver (2007). Using Software in Qualitative Research. Forum: Qualitative Social Research: 10(1).

BRENOVA. 2015. 32. Prĩzkum AMSP ČR (Asociace malých a středních podnikü a živnostníků České republiky) - Rodinné firmy. [Online]. Available at: http://amsp.cz/32-pruzkum-amsp-cr-rodinne-firmy/ [Accessed: 2017 December, 10].

BOTERO, I. C., GOMEZ BETANCOURT, G., BETANCOURT RAMIREZ, J. B., and LOPEZ VERGARA, M. P. 2015. Family protocols as governance tools. Journal of Family Business Management, 5(2): 218-237.

CASTILLO-APRAIZ, J. and MATEY, J. 2015. Effect of competitive tactics on performance: The case of the pharmaceutical industry. In: Proceedings of Twente University, $2^{\text {nd }}$ International Symposium on Partial Least Squares Path Modeling - The Conference for PLS Users. Twente University of Seville, 16-19 June, Spain. Available at: https://goo.gl/ZB4bzG. [Accessed: 2016, October 16].

CHEZURIANA, J. M. and MOHAMED, R. 2011. Performance Measurement System (PMS) in Small Medium Enterprises (SMES): A Practical Modified Framework. World Journal of Social Sciences. 1(3): 200-212.

CHRISMAN, J. J., CHUA, J. H., PEARSON, A. W., et al. 2012. Family involvement, family influence, and family-centered non-economic goals in small firms. Entrepreneurship Theory and Practice, 36(2): 267-293.

CHRISTOFI, M., LEONIDOU, E. and VRONTIS, D. 2015. Cause-related marketing, product innovation and extraordinary sustainable leadership: the root towards sustainability. Glob. Bus. Econ. Rev., 17(1): 93-111.

CONNELLY, L. M. 2008. Pilot studies. Medsurg nursing: official journal of the Academy of Medical-Surgical Nurses, 17(6): 411-412.

DE MASSIS, A., KOTLAR, J., CAMPOPIANO, G. and CASSIA, L. 2013. Dispersion of family ownership and the performance of small-to-medium size private family firms. Journal of Family Business Strategy, 4(3): 166-175.

FIORE, M. et al. 2017. Understanding the relationship between green approach and marketing innovations tools in the wine sector. Journal of Cleaner Production, 142(P4): 4085-4091.

HERNÁNDEZ-LINARES, R., SARKAR, S. and COBO, M., 2018. Inspecting the Achilles heel: a quantitative analysis of 50 years of family business definitions. Scientometrics, 115(2), 929-951. 
HERTZOG, M. A. 2008. Considerations in determining sample size for pilot studies. Research in Nursing $\sigma^{\circ}$ Health, 31(2): 180-191.

HESKOVÁ, M. and VOJTKO, V. 2008. Rodinné firmy: zdroj regionálního rozvoje, Zeleneč: Profess Consulting.

HILL, R. 1998. What sample size is "enough" in internet survey research? Interpersonal Computing and Technology: An Electronic Journal for the 21st Century, 6(3-4).

HORNUNGOVÁ, J., and MILICHOVSKÝ, F. 2013. Profit indicators in performance systems in the Czech companies. Acta Universitatis Agriculturae et Silviculturae Mendelianae Brunensis, 61(2): 345-352.

ISAAC, S., and MICHAEL, W. B. 1995. Handbook in research and evaluation. San Diego, CA: Educational and Industrial Testing Services.

JANKU, M. and MAREK, K. 2016. Family Enterprise in Czech Civil Code. EU agrarian Law, 5(2): 25-32.

JULIOUS, S. A. 2005. Sample size of 12 per group rule of thumb for a pilot study. Pharmaceutical Statistics, 4(4): 287-291.

KAMSU-FOGUEM, B. and FLAMMANG, A. 2014. Knowledge description for the suitability requirements of different geographical regions for growing wine. Land Use Policy, 38: 719-731.

KLEIN, S. B., ASTRACHAN, J. H. and SMYRNIOS, K. X. 2005. The F-PEC Scale of Family Influence: Construction, Validation, and Further Implication for Theory. Entrepreneurship: Theory and Practice, 29(3): 321-339.

KORÁB, V., HANZELKOVÁ, A. and MIHALISKO, M. 2008. Rodinné podnikání: zpưsoby financování rodinných firem, ř́izení rodinných podnikư, úspěšné predání následnictví. Brno: Computer Press.

LING, Y., and KELLERMANNS, F. W. 2010. The effects of family firm specific sources of TMT diversity: The moderating role of information exchange frequency. Journal of Management Studies, 47(2): 322-344.

LOMBARDI, P, DAL BIANCO, A., FREDA, R., CARACCIOLO, F. and CEMBALO, L. 2016. Development and trade competitiveness of the European wine sector: A gravity analysis of intra-EU flows. Wine Economics and Policy, 5(1): 50-59.

LÓPEZ-GUZMÁN, T., RODRÍGUEZ-GARCÍA, J., SÁNCHEZ-CAÑIZARES, S. andJOSÉ LUJÁN-GARCÍA, M. 2011. The development of wine tourism in Spain. International Journal of Wine Business Research, 23(4): 374-386.

MARTIN-REYNA, J. M., and DURAN-ENCALADA, J. A. 2012. The relationship among family business, corporate governance and firm performance: Evidence from the Mexican stock exchange. Journal of Family Business Strategy, 3(2): 106-117.

MASON, M. C., GOS, L. and RAGGIOTTO, F.2016. Entrepreneurial orientation, agglomeration, networks and firms' performance - Empirical evidence from the Italian wine sector. International Journal of Entrepreneurship, 20(1): 100-128.

MAZZI, C., 2011. Family business and financial performance: Current state of knowledge and future research challenges. Journal of Family Business Strategy, 2(3): 166-181.

MAZZOLA, P., SCIASCIA, S. and KELLERMANNS, F. 2013. Non-linear effects of family sources of power on performance. Journal of Business Research, 66(4): 568.

MILLER, D., LE BRETON-MILLER, I., LESTER, R. H., and CANNELLA, A. A. 2007. Are family firms really superior performers?. Journal of Corporate Finance, 13(5): 829-858.

MURÍNOVÁ, A. 2017. Wine Marketing: The Case of Micro and Small Wine Companies in the Czech Republic. In: Proceedings of the $5^{\text {th }}$ International Conference Innovation Management, Entrepreneurship and Sustainability (IMES 2017). 25-26 May. Prague: University of Economics. Oeconomica Publishing House, 5, pp. 641-653.

MURINOVA, A. 2017. Family Relationships and its Influence on Family Wine Firms in the Czech Republic. Trendy Ekonomiky a Managementu, 11(29): 51-58.

PETLINA, A. 2016. Key Principals of Family Business Comprehension with Help of the Historical Analysis. In: Proceedings of the $4^{\text {th }}$ International Conference "Innovation Management, Enterpreneurship and Corporate Sustainability", (4): 557-570.

ROZBROJ, D. 2014. Situační a Vúhledová Zpráva. Réva Vinná a Víno. Praha: Ministerstvo Zemědelství. Available at: http://eagri.cz/public/web/file/433552/SVZ_Vino_2015.pdf [Accessed: 2017, December 10].

SIMPSON, M., PADMORE, J. and NEWMAN, N. 2012. Towards a new model of success and performance in SMEs. International Journal of Entrepreneurial Behaviour $\odot$ Research, 18(3): 264-285.

RICHARD, P. J., DEVINNEY, T. M. and JOHNSON, G. 2009. Measuring Organizational Performance: Towards Methodological Best Practice, Journal of Management, 35(3): 718-804.

ŠPERKOVÁ, R., and HEJMALOVÁ, H. 2012. Intensity of rivalry among existing competitors in the winemaking branch. Acta Univ. Agric. Silvic. Mendelianae Brun., 60(2): 429-436.

SIMPSON, M., PADMORE, J. and NEWMAN, N. 2012. Towards a New Model of Success and Performance in SMEs. International Journal of Entrepreneurial Behaviour $\nleftarrow$ Research, 18(3): 264-285.

LAEVAERT, C. 2016. Small and Medium-Sized Enterprises (SMES). Eurostat: Your key to European statistics. [Online]. Available at: http://ec.europa.eu/eurostat/web/structural-business-statistics/ structural-business-statistics/sme [Accessed: 2016, December 17].

SOLER, I. P., GEMAR, G. and GUERRERO-MURILLO, R. 2017. Family and Non-family Business Behaviour in the Wine Sector: A Comparative Study. European Journal of Family Business, 7(1-2): 65-73. 
SVOBODOVÁ, I., VĚŽNÍK A., and KRÁL, M.,2014. Viticulture in the Czech Republic: Some Spatio-Temporal Trends. Moravian Geographical Reports, 22(1): 2-14.

VALLONE, C. 2013. Contribution on Family Business Definition. In: The Firm's Role in the Economy: Does a Growth - Oriented Business Model Exist? In: Proceedings of the $36^{\text {th }}$ AIDEA Conference. Bari: Cacucci. Available at: http://hdl.handle.net/10281/46789 [Accessed: 2017, June 30].

VAN BELLE, G. 2002. Statistical rules of thumb. New York: John Wiley.

YU, Y. and LINDSAY, V. 2016. Export Commitment and the Global Financial Crisis: Perspectives from the New Zealand Wine Industry. Journal of Small Business Management, 54(2): 771-797.

WIECEK-JANKA, E., MIERZWIAK, R. and KIJEWSKA, J. 2016. Competencies' Model in the Succession Process of Family Firms with the Use of Grey Clustering Analysis. Journal of Grey System, 28(2): 121-131. 